Journal of Educational Method and Technology Vol. 2 No. 2, Agustus 2019

P-ISSN 2622-8459 E-ISSN 2622-8467

http://ejournal.unima.ac.id/index.php/jemtec

\title{
A Study On Physical Changes The Traditional Houses of Minahasa And Toraja In Indonesia
}

\author{
M F Suharto ${ }^{1}$ \\ ${ }^{1}$ Universitas Negeri Manado, Indonesia \\ corresponding author: ${ }^{1}$ fachruddinsuharto@unima.ac.id
}

\begin{abstract}
The aim of this research is to identify the physical changes that occur on the traditional houses of Minahasa and Toraja, including factors that cause the physical changes. Furthermore, we analyze the possibility of significant similarities and differences that exist on both the traditional houses. Based on the purposive sampling studies and literature studies, the discussion and analysis of the physical changes will include the physical elements of architecture which consist of form (design), structure and construction, materials, layout plan, and ornament. The results of this study indicate that the technology development, the natural influence, physiological needs as well as an increase in the fulfillment of social needs and the development of civilization has affected the physical changes. Of all the elements of the architecture that have been reviewed, we found that not all elements occur of the same physical changes and significant.
\end{abstract}

\section{Keywords: Physical changes, Traditional houses, Minahasa, Toraja}

\section{Introduction}

The traditional houses Minahasa and Toraja are two of the many traditional houses in Indonesia. The houses are embodiment of the culture and the system of local community life which are born and grow without being affected by the presence of the global architecture. Traditional houses of Minahasa and Toraja are two representatives that depict the diversity and property of various forms of traditional houses in Indonesia. However, the diversity and wealth from the form of those traditional houses are often recognized only as visual variety. Until now, the studies of traditional houses tend to discuss the values of traditions and customs outlined by the ancestors. These values shaped into the physical formations of the building.

Over time, despite the existence of the phenomenon that traditional houses are still used as a dwelling, there have been physical changes due to internal and external influences. According to Sardadi Baskoro in Budihardjo Eko (1997) ${ }^{1}$, he stated that the improvement of technology, communication tools, and open mindset from the society have changed the values of traditional houses. According to Habraken in Karsono Danarti $(2011)^{2}$, Changes a building site that becomes subject is space and materials having volumes, composition and structure. Furthermore, Karsono Danarti summarizes several the results of research about the part of the house often changes are ; a. Outer walls, doors, windows on the facade because of the influence of modernization or the need for privacy $b$. function and the width of the space, lay-out space for the needs of its inhabitants both for economic (business), for families and for the need for privacy. c.Density or basic building coefficient for 
Journal of Educational Method and Technology Vol. 2 No. 2, Agustus 2019

P-ISSN 2622-8459 E-ISSN 2622-8467

http://ejournal.unima.ac.id/index.php/jemtec

family development or economic needs, and d.Building materials, due to the influence of modernization.

Therefore, this study aims to explain the physical changes and factors that influence the changes, also to searching similarities and differences found in the physical changes. Through methods the purposive sampling studies and literature studies, this paper begins with the study of traditional houses of Minahasa from before 1845-1945 and after 1945, and study of traditional houses of Toraja from before and after 1940s. Further, study to explain the physical changes, the similarities and differences of physical changes and ends with the conclusion.

\section{Study of the Traditional Houses of Minahasa and TorajaClass Management}

History and Physical Character of the Traditional House of Minahasa

The traditional house of Minahasa called as Wale. The design of Minahasan traditional house is the stilts house built on on the land or on the water. Most of the material used is wood ranging from the construction of buildings, floors, walls and other parts of building. The material is taken from some species of trees grew in the forests inside Minahasa area (N. Graafland in Harimu Debby, Minahasa Arsitektur, $2013 ; 66)^{3}$. According to Mamengko in Harimu Debby $(2013 ; 71)^{4}$ the development of Minahasan traditional houses can be divided into three periods ; the period before the earthquake of 1845, the post-earthquake period 1845-1945 (Dutch colonial period reshtsreeks bestuurd gebeid) ${ }^{\text {(Fig.1) }}$ and the period after $1945^{\text {(Fig.2) }}$.

According to N. Graafland in Harimu Debby, $(2013 ; 69)^{5}$ is not known exactly when the first period, when the arrival of the western nations to Minahasa, the Minahasan people have made a big house with a big tall masts and inhabited more than 10-20 families. From the bibliographic records of Minahasa, it is known that before the arrival of the western nations, the Minahasans have had a fixed life pattern. And when they started to get acquainted with the western nations or foreigners, the Minahasans have made a home with a large size with columns high and large as well. This house is inhabited by a large number of family members uxorilocal ${ }^{6}$. Years after the earthquake, the design of Minahasan traditional houses become smaller. The columns also made shorter than the previous one. These changes were later passed on from generation to generation. Until present day, there are some villages that currently have the 'old houses' that are recognized as Minahasan traditional houses (Samsyiddar 1991; 194-199 in Harimu Debby, 2013; $70)^{7}$. include;

Physical aspects of architectural contained in a traditional house of Minahasa

a. The basic form (design) of formal structure a traditional house of Minahasa is rectangular.

b. Construction of the house has the form of a stilts house, which consists of 4 sections: The first is Kolong space (empty space underneath), before the great earthquake (1845) supported by round columns with measurement $\pm \varnothing 80$ $200 \mathrm{~cm}(2,6-6,6 \mathrm{ft})$ and approximately $2.5-10 \mathrm{~m}(8,2-32,8 \mathrm{ft})$ high. While after $1900 \mathrm{~s}$ rectangular column with size $40 \times 40 \mathrm{~cm}$ up to $20 \times 20 \mathrm{~cm}$ and approximately $1,5-2,5 \mathrm{~m}(4,9-8,2 \mathrm{ft})$ high. Number of columns approximately between 16 to 18 columns and placed on a white stone called watulanei with 
Journal of Educational Method and Technology Vol. 2 No. 2, Agustus 2019

P-ISSN 2622-8459 E-ISSN 2622-8467

http://ejournal.unima.ac.id/index.php/jemtec

size $\pm 15-20 \mathrm{~cm}(0,49-0,65 \mathrm{ft})$. In after 1900 have the bearing beams down that has a size same as column ${ }^{\text {(Fig.4). }}$. The second is the upper of house consisting of wood frame wall construction, floor beams and attic beams by using a the pegs connection system (Fig.6). The third is the roof construction made of beams measuring $10 \times 10 \mathrm{~cm}$ and $15 \times 15 \mathrm{~cm}$. Design of the roof truss is a combination of design pyramid roof and gable roof. Wooden connection system using the pens connection system (Fig.8). The fourth is Stairs. Generally, the house of Minahasa has 2 stairs placed in front and in the behind, or both in front of and facing each other. The stairs also use a wooden construction with the pens connection system. The stairs have a 7,9 or12 rungs (Syamsidar 1991; 197 in Harimu Debby, 2013; 86) (Fig.10). $^{\text {(10. }}$

c. Almost all building materials from forest. For columns, beams, walls, floors and sills, all made up of wood. If there was no wood would be used bamboo or Nibung (a type of palm). Material of roof covering using rumbia leaves (Metroxylon rumbiana) called as katu roof. Materials to tie roof truss using palm fiber rope or rattan and bamboo pegs ${ }^{\text {(Fig.24). }}$

d. Layout-plan before 1845 knows only one big middle space where people do all the activities, however after 1900s has had more spaces according to the needs (N.Graafland 1864; 236 in Harimu Debby, 2013;75) ${ }^{9}$. The mass of the building on 1900s is lined extends to the rear. In the front row is the core of the building. The kitchen located in the back of the building. On one side there is a well behind the house and the bathroom. At the back, a little further from the main house, there is a toilet or latrine and pigsties ${ }^{\text {(Fig.20). }}$

e. The applications of ornaments in Minahasan house are relatively less, implying the simple characteristic of Minahasan people and how they tend to give more focus on practical issues in their life ${ }^{\text {(Fig.28) }}$. The domination of ornament pattern derived from natural forms (flora and fauna) also showed a high appreciation of the Minahasan community against the natural physical environment. This has seen as the most beautiful blessing of the Opo Empung (god almighty).

\section{History and Physical Character of the Traditional House of Toraja}

The traditional house of Toraja has several designations. The most famous is the Tongkonan. Kis-Jovak (1988) ${ }^{10}$, states that Torajan people call the Tongkonan as Banua which means a small depiction of the world (The Microcosm). It is also in line with the statement of Dawson and Gillow (1994) ${ }^{11}$, they mention that Torajan house can be called Banua Toraja or Tongkonan. The tongkonan is traditionally perceived as the navel of the universe and a miniature cosmos (Parinding Samban, 1988;73) ${ }^{12}$. The development of a traditional house of Toraja has existed since the Mesolithic era. Initially people live in caves, and then they build houses using wood and evolved into a traditional house design as it exists today.

According to Kis-Jovak in Nurdiah Esti A, $(2011 ; 30)^{13}$, based on the its role and functions, the houses of Toraja divided into 5 types ; 1. House (Banua/Tongkonan) 2. Granary (Alang) 3. Home guards rice, 4. Animal cages, and 5. Funeral homes. Tongkonan also divided into three levels, namely, a.Tongkonan Layuk, a place to create the custom rules, b. Tongkonan Pokamberan, a place to implement custom rules, and c. Tongkonan Batu A riri a place to coach the family 
members. According Tangdilinting in Sumalyo Yulianto, $(2001)^{14}$ There is a theory expressed by many researchers and observers about stories of the Torajan people, about the development of traditional house of Toraja that evolved from the design of flat roof become curved roof like that exists today. The first form is Banua Lentong A 'pa', the second development is Banua Tamben, the third is Banua Sanda A riri and the latter is Tongkonan which has a curved roof ${ }^{\text {(Fig.3). }}$.

The empty space underneath (Kolong space) is used only for the cages of buffalo, with no other animals allowed to here. Right above this space lies the living quarters, which is roofed like a giant ship. This living area is divided into three parts, each has different functions. Entrance door is located at the east or north side, never at the west or south side. The Torajan houses are decorated with series of buffalo horns on the supporting column. This particular decoration is an important symbol of wealth and social status for the owner (Samingoen Sampoerno 1983/1984) ${ }^{15}$. Torajan people had a religion of their ancestors called Aluk Todolo. Aluk Todolo is very influential in all activity in Toraja's community, including become a determinant in the construction of traditional houses. (Sumalyo Yulianto, 2001) ${ }^{16}$. Additionally, Tongkonan belong together from a large family, therefore everything related to the Tongkonan house must go through a joint decision of the meeting of members of the family (Damanik I. I, 2012) ${ }^{17}$. include;

Physical aspects of architectural contained in a traditional house of Toraja,

a. The design is rectangular, with the longitudinal position of the direction of the sunrise and the sunset. The size varies between $3-4 \mathrm{~m}(9,8-13,1 \mathrm{ft})$. Comparison of the width and the length varies between 1:2 to 1:2,5, so a length of about 8-10m (26,2-32,8 ft) (Sumalyo Yulianto, 2001) ${ }^{18 .}$

b. The construction of the traditional house of Toraja always in the form of a stilts house. Construction of wooden columns and beams to form horizontal and vertical elements, this is a common characteristic of traditional house emblems of the relationship between humans and nature. (Sumalyo Yulianto, $2001)^{19}$. The foundation system used river stones or stones from the mountain (Fig.12). Columns are rectangular and arranged in rows as well as bound with horizontal beams called roroan $b a^{\prime} b a$ and usually amount to 2-3 blocks. The number of columns on the side of the longitudinal follow the length of the house usually amount to 9-12 columns (Nurdiah Esti A, 2011) ${ }^{20}$. At the center position slightly to the rear there is a column called a'riri (milestone) posi (navel) decorated and carved, but different from the others. A'riri posi is a centre milestone in the Torajan traditional house is a symbol of unity between man and the earth. Usually sized $22 \times 22 \mathrm{~cm}$ or $20 \times 20 \mathrm{~cm}$ (Sumalyo Yulianto, 2001) $)^{21}$. The floor of the Tongkonan supported by beams and columns are large square and heavy. Meeting column with floor beams using pens and pegs. The wall of the Tongkonan is panels wooden panels and frame size $5 \times 25 \mathrm{~cm}$ or $6 \times 25 \mathrm{~cm}$ with the thick $3-4 \mathrm{~cm}(0,09-0,13 \mathrm{ft})^{(\text {Fig.14) }}$. Roof truss of the Tongkonan made rods of wooden and bamboo (Fig.16). Stairs use a wooden construction with the pens connection system $^{(\text {Fig.18). }}$.

c. The traditional house of Toraja is dominated by wooden and bamboo materials. The columns, beams and the floor construction using Uru wooden. The frame of the wall with the filler of wall using palm wood. Frame of roof 
Journal of Educational Method and Technology Vol. 2 No. 2, Agustus 2019

P-ISSN 2622-8459 E-ISSN 2622-8467

http://ejournal.unima.ac.id/index.php/jemtec

made of bamboo structure mounted overlap and tied with rope bamboo or rattan, and the roof covering made of plaited the rumbia leaves ${ }^{(\text {Fig.26) }}$.

d. Layuot plan, according to Said A. Aziz in Stephany Sandra (2009) $)^{22}$ explained according to the teachings Aluk Todolo, the universe is divided into three parts ; the first, "Top of the World" is the abode Puang Matua (God Most High), the second, "Middle-earth" are on the surface of the earth where human beings live their lives, and the third, "Underworld" is under water, identified as subordinate and bad (hell). The division of the universe is based on the belief Aluk Todolo later became the basis of the realization of the formation concept of the Tongkonan. Space in the Tongkonan divided into three parts: The front space (Tangdo ') called Kale Banua facing north. Place of the presentation of sacrificial offerings and custom ceremonies. Living room (Sali) wider and a bit lower than other spaces. Divided over the left (west) place of the animal sacrifice ritual offerings Aluk Rambu Solo 'and the right part (east) place of the sacrificial offerings in the ceremony Aluk Rambu Tuka'. The back room (Sumbung) called Pollo Banua (the tail) is at the south, place of the entry of the disease ${ }^{\text {(Fig.22). }}$

e. The Tongkonan is rich with forms ornament of animals, plants and space objects also the variegated of colors. Ornaments with the animal form symbolizes strength and power, ornamental plants symbolize prosperity, and space objects symbolizes the power of God. While the use of color gives the impression of a red color means the courage to sacrifice, yellow means majesty, black means kindness, and white means independence. references to the status of the tongkonan are found in the mere fact of its carrying carved decoration and in such attached ornament as a wooden buffalo head, kabango protruding from the post supporting the roof projection in front of the house, the long necked chicken, katik, on top of the house in commemoration of ritual sacrifices made in fulfilment of the Aluk (Parinding, Samban C, 1988;79) ${ }^{23(\text { Fig.30). }}$.

\section{Physical Changes of the Traditional House of Minahasa and Toraja}

To explain the physical changes that observed in the traditional house of Minahasa and Toraja, it can be seen in the physical elements of architectural which consist of; the form (design), structure and construction, layout, materials and ornaments.

\section{a. The Form (Design)}

Overall the basic form of traditional house of Minahasa and Toraja did not changes. Minahasan houses generally have symmetric properties where same elements on the left and right . Design changes on the tongkonan house only found in the form of the roof, which is an evolution changes from the tongkonan form ancient times. Previously had a flat roof from then gradually evolved into form of the curved roof. The form of the curved roof occurred since the 8th century and has not changed to the present. (Table.1)

\section{b. Structure and Construction}

In Kolong space (empty space underneath) in the Minahasan houses experienced significant changes. The foundation stone elements (watulanei), previous use of natural stone foundation changed using cast concrete until 
now. The form changes of the column in before 1845 round form with a large enough size $(80-200 \mathrm{~cm} / 2,6-6,6 \mathrm{ft})$ and $(2.5-10 \mathrm{~m} / 8,2-32,8 \mathrm{ft})$ high , while after 1900 s form of the column turned into a rectangular with a smaller size $(40 / 40 \mathrm{~cm}$ up to $20 / 20 \mathrm{~cm})$ and lower $(1.5-2.5 \mathrm{~m} / 4,9-8,2 \mathrm{ft})$, Also there are the bearing beams down, however have been ignored until now (Fig.5). To the upper of house there are not fundamental changes. Changes only occur on the windows construction; previously the windows form is 2 wings have turned into the nako windows or jalousie with the glass material ${ }^{\text {(Fig.7). }}$. At first the use of the roof construction is to use the roof rafter construction, changes into combination of design pyramid roof and gable roof ${ }^{\text {(Fig.9). }}$ Minahasan houses still maintained the position of 2 pieces of stairs in front of the house, located on the left and right front of the house; with the number of steps have an odd number. Also still maintains 1 stair located at the front and one in back of the house ${ }^{\text {(Fig.11). }}$

Table 1 : The physical changes on the elements of the form (Design)

\begin{tabular}{|c|c|c|}
\hline The Traditional House & The Earlier forms & The Physical Changes \\
\hline $\begin{array}{c}\text { The Wale } \\
\text { (Minahasan House) }\end{array}$ & Fig, 1 the development of Minahasa traditional house & $\begin{array}{l}\text { After 1900s Now } \\
\text { Fig.2 the development of Nemahasa traditional house }\end{array}$ \\
\hline $\begin{array}{l}\text { The Tongkonan } \\
\text { (Torain House) }\end{array}$ & $\begin{array}{l}\text { Pandoko Dena' Lentong Ang' (BC) } \\
\text { Fig.3 the development of traditional house of Toraia }\end{array}$ & $\begin{array}{c}\text { Tongkonan After 1940s } \\
\text { Fir.3 the davelormentof traditional houre of Toraia. }\end{array}$ \\
\hline
\end{tabular}

Similar to the traditional house of Minahasa, part of the foundation of Torajan house also changing from the use of natural stone with cast concrete foundation. The ancient times, design of columns is round then changed to be rectangular. Beams on the empty space underneath are the most important element in the Torajan house, because it can function as a binder or stiffener of the columns buffer ${ }^{\text {(Fig.13). The }}$ upper of the Torajan house generally do not experienced significant changes, just a little change in the arrangement of the space, which has changed the function on after

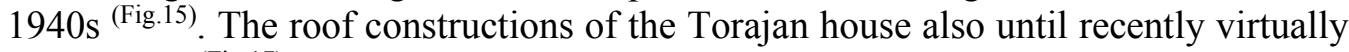
unchanged (Fig.17). Changes of the structure and construction are influenced by technological developments and natural influences. (table.2). 
Journal of Educational Method and Technology Vol. 2 No. 2, Agustus 2019

P-ISSN 2622-8459 E-ISSN 2622-8467

http://ejournal.unima.ac.id/index.php/jemtec

Table 2 : The physical changes on the elements of the Structure and

Construction

\begin{tabular}{|c|c|c|}
\hline $\begin{array}{c}\text { The } \\
\text { Traditional } \\
\text { House }\end{array}$ & The Earlier forms & The Physical Changes \\
\hline $\begin{array}{c}\text { The Wale } \\
\text { (Minahasan } \\
\text { House) }\end{array}$ & \begin{tabular}{|l} 
Fig.6 The upper stucture \\
3. Frame of roof before $1900 \mathrm{~s}$ \\
1900s \\
Fig.8 The roof construction \\
4. Stairs \\
Fig.10 The stairs construction and placement \\
position
\end{tabular} & $\begin{array}{l}\text { Foundation Columns Beams } \\
\text { Fig.5 The physical changes of the Kolong structure } \\
\text { Elements of the wall pillar, upper bearing, } \\
\text { the window sill crossbar (after 1900s) } \\
\text { Fig.7 The physical changes of the upper structure }\end{array}$ \\
\hline $\begin{array}{c}\text { The } \\
\text { Tongkonan } \\
\text { (Torajan } \\
\text { House) }\end{array}$ & $\begin{array}{l}\text { Foundation Beams Columns } \\
\text { Fig.12 The Kolong of Torajan house(before } \\
\text { 1940s) } \\
\text { 2. The upper of house }\end{array}$ & 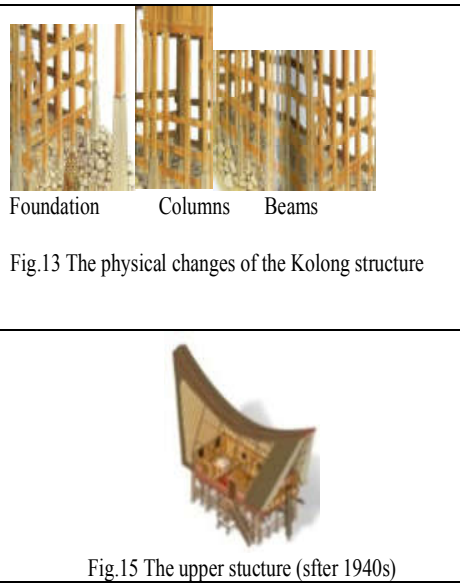 \\
\hline
\end{tabular}




\section{Layout Plan}

Layout plan of the traditional house of Minahasa and toraja experienced significant physical changes. Before 1845, the Minahasa people live in groups and have only one big space; however after 1900s some space has been added with permanent wooden partitions wall. Layout plan consists of; on the front is a terrace, and then there is a pore, further bedroom with position facing each other, and dining room at the back. The main building was separate from the kitchen bathroom and wells. While toilet and animal cages are separate further away from the main building. ${ }^{\text {(Fig.21). }}$.

The change of layout of Tongkonan house occur in the section Tangdo, Sali, and Sumbung, which today serves as a living quarters, because in ancient times only used for custom event alone. Especially on Tongdo section is no longer functioned as a place to perform the ritual. This is because the owner is no longer closely tied to

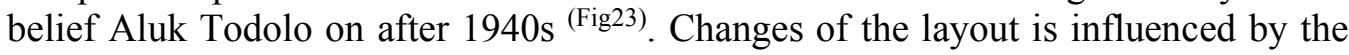
development of civilization and religious, technological developments and physiological needs as well as an increase in the fulfillment of social needs.(Table.3)

Table 3 : The physical changes on the elements of the Layout Plan

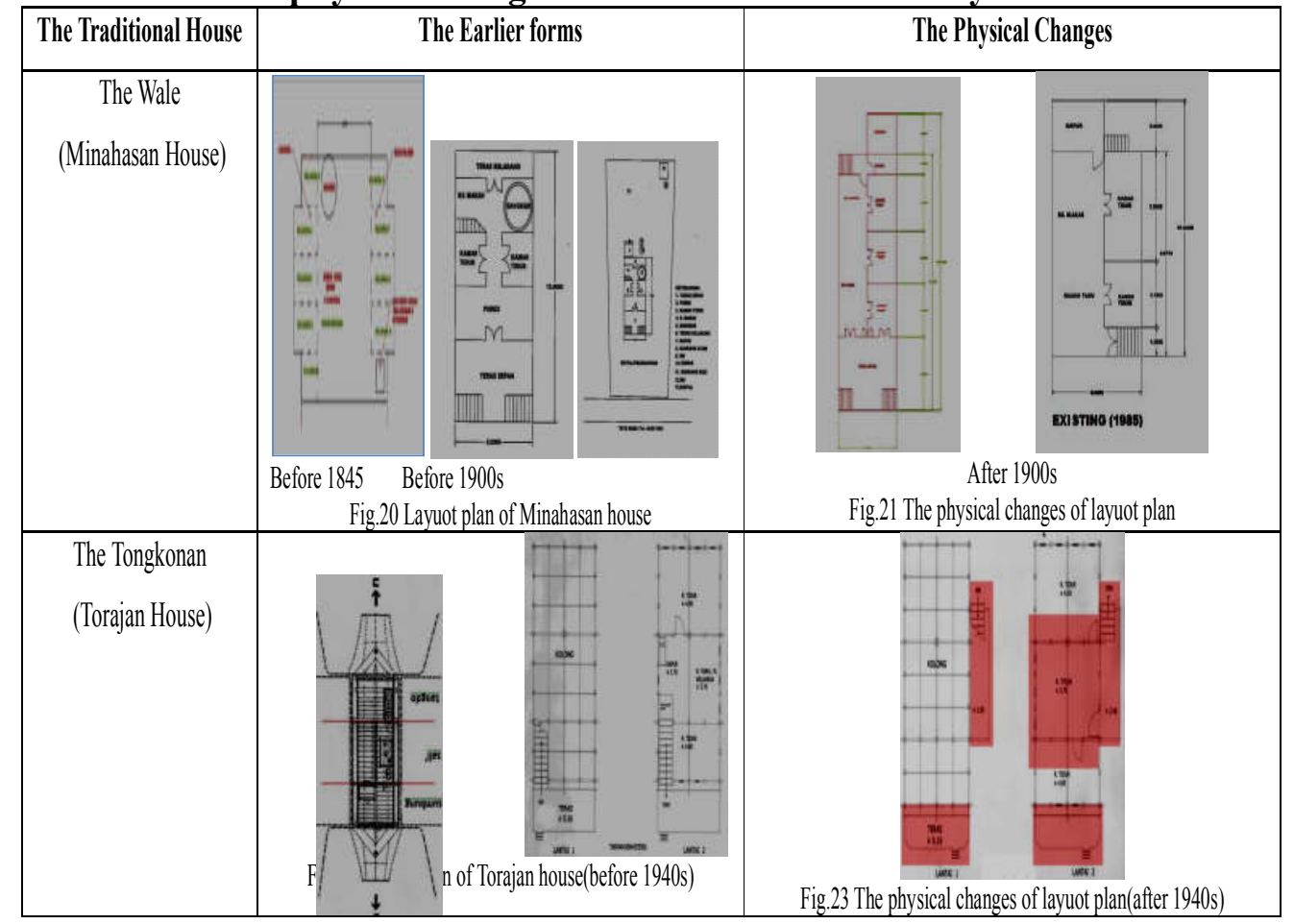

\section{a. Material}

Changes in the use of materials on the traditional house of Minahasa and Toraja experienced the same significant changes. Roof covering material at the ancient house using rumbia leaves, further there are the influence of foreign culture (development of civilization) and technological development have changed into zinc aluminum material. In addition to roof covering material, material changes also occur in the rock foundation, columns and stairs are that using concrete. Changes in the use 
of materials also occur on the floor who have used ceramic tiles and the windows have been using glass materials. (Fig.25 and 27) (table.4).

\begin{tabular}{|c|c|c|}
\hline The Traditional House & The Earlier forms \\
\hline The Wale & Minahasan House) \\
\hline The Tongkonan \\
(Torajan House)
\end{tabular}

Table 4 : The physical changes on the elements of the Material

\section{b. Ornaments}

The traditional house of Minahasa has very few ornaments, and still the same as the ancient form. ${ }^{\text {(Fig.29) }}$ The use of ornaments in traditional house of Toraja is a must, because it is a visual appeal beside the design of the roof. In addition, the ornament has an important meaning for the life of its owner. The change is only on the difference in complete or incomplete ornaments (Kabongo and katik, tulak somba and posi' a 'riri). Although ornaments not look complete, but still has the same function by replacing ornament in the form of another. ${ }^{\text {(Fig.31) }}$ (Table.5)

Table 5 : The physical changes on the elements of the Ornaments

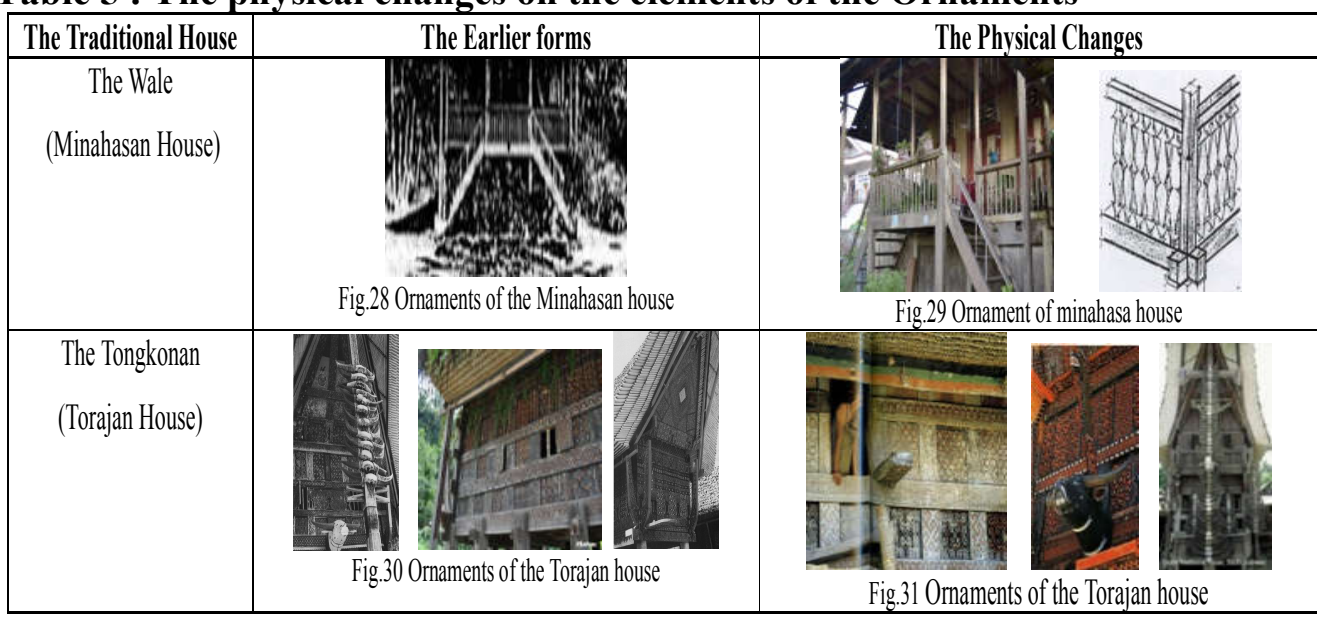

\section{Similarities and Differences in Physical Change}

Similarities and differences on both the traditional houses, be reviewed of the process of physical changes can be seen in the table below (table 6). Similarities and differences on both the traditional houses, be reviewed of the process of physical changes can be seen in the table below (table 6). 
Table 6 : The physical changes of the traditional house of Minahasa and Toraja in Similarities and Differences

\begin{tabular}{|c|c|c|c|c|c|c|c|c|c|c|c|c|}
\hline \multirow{4}{*}{$\begin{array}{c}\text { Traditional } \\
\text { Houses }\end{array}$} & \multicolumn{12}{|c|}{ The Physical Changes } \\
\hline & \multirow{3}{*}{$\begin{array}{c}\text { Form } \\
\text { (Design) }\end{array}$} & \multicolumn{8}{|c|}{ Structure and Construction } & \multirow{3}{*}{\begin{tabular}{|c|} 
Layout \\
Plan
\end{tabular}} & \multirow[t]{3}{*}{$\begin{array}{l}\text { Material } \\
\end{array}$} & \multirow[t]{3}{*}{ Omament } \\
\hline & & \multicolumn{3}{|c|}{ The empty space underneath } & \multicolumn{3}{|c|}{ The upper of house } & \multirow{2}{*}{$\begin{array}{c}\text { The roof } \\
\text { construction }\end{array}$} & \multirow[t]{2}{*}{ Stairs } & & & \\
\hline & & $\begin{array}{c}\text { Foundatio } \\
n\end{array}$ & Column & Beam & wall & floor & $\begin{array}{c}\text { Doorl } \\
\text { window }\end{array}$ & & & & & \\
\hline $\begin{array}{c}\text { The Wale } \\
\text { (Minahasan } \\
\text { House) }\end{array}$ & $\Delta$ & 0 & 0 & 0 & $\Delta$ & $\Delta$ & 0 & 0 & 0 & 0 & 0 & \& \\
\hline $\begin{array}{c}\text { The } \\
\text { Tongkonan } \\
\text { (Torajan } \\
\text { House) } \\
\end{array}$ & 0 & 0 & 0 & $\mathbf{\psi}$ & $\Delta$ & 0 & $\Delta$ & \& & 0 & 0 & 0 & $\Delta$ \\
\hline $\begin{array}{l}\text { Similarities } \\
\text { and } \\
\text { Differences }\end{array}$ & $Q$ & 0 & 0 & $Q$ & 0 & $Q$ & $Q$ & $Q$ & 0 & 0 & 0 & $Q$ \\
\hline
\end{tabular}

\begin{tabular}{|l|l|l|l|l|l|l|l|l|l|}
\hline$\Delta$ & Fixed and changes & $\mathbf{0}$ & Changes & No Changes & $\mathbf{0}$ & Similarities & $\mathbf{Q}$ & Differences \\
\hline
\end{tabular}

\section{Source: Analysis of the author}

The design or basic form the traditional house of Minahasa and Toraja have the same form is rectangular. Design of the Minahasan house from the ancient times no fundamental changes. Similarly Toraja house design is still maintained, although previously experience evolution on the roof form.

On the elements of the structure and construction experienced significant changes of both the traditional houses. Physical changes in the Kolong space contained in almost all the physical elements that consist of foundations, columns and beams. Similarities exist in the material changes of foundation stone, on the ancient home using natural stone has been replaced with cast concrete on after 1900s.Similarly, design of columns previously large and round, turned into a rectangular shape with a smaller size and lower. On the bearing beams down, there is a difference, in the Minahasan house has been ignored on after the 1900s, while the use of beams in Toraja traditional house still maintained until now. The structure on the upper of house, generally do not much experience changes. On the Minahasan house is dominated by the replacement of the materials on the window and door elements, while the elements walls and floors experienced of wood replacement due to the influence of the age of the wood. At the Torajan house experienced the physical changes in the structure at the upper of house, because there are changes of function. Physical changes at the floor construction, in the ancient times there are differences in height of the floor but after 1940s had been reduced almost flat.

Physical changes on the roof construction there are differences. The ancient Minahasan house using the rafter roof construction changed to combination of design 
pyramid roof and the gable roof. Whereas Toraja house has not changed and is still using bamboo roof construction with arrangement mounted overlap.

The stairs construction on the traditional house of Minahasa and Toraja generally are still using the construction of wooden stairs, although there are already using concrete materials. The layout position the stairs on both the traditional houses still maintained the same as the position on the ancient house.

Layout plan on both the traditional houses is experienced significant physical changes. The Minahasan house before 1845 had only a large room changed have more rooms in after 1900s. The same thing also happened on the Torajan house on after 1940s. The other similarities of both the traditional houses have changed the function of the kolong space with the other functions according to the times.

Material changes that look more dominant of both the traditional houses, contained on the elements of the roof covering, which the ancient house using rumbia leaves and changed using zinc aluminum. In addition to, there are also the changes of material at the foundation stone, columns, and stairs that have used concrete. The use of glass material for window elements there in the Minahasan houses. And on current developments to the floor and stairs have been using ceramic tile material.

In ornament elements of both the traditional houses only there is a difference in the quantity, which the Torajan house has rich the ornaments while the Minahasan house has very few the ornaments.

\section{Conclusion}

Based on the study reviews above, the conclusions of the research are as follows:

1. Generally the traditional houses of Minahasa and Toraja have experienced physical changes.

2. Physical changes on the both traditional houses looks more significantly on the material elements and structure, because of the influence by development of technology, the natural influence, development of civilization as well as increased social status.

3. The development of the layout plan because of physiological needs, although the design of basic form is still maintained. Especially in Toraja traditional house, the ancient times be the place for a custom event but now as a residence. This is because many people who have left the religion Toraja ancestors.

4. The similarities of the physical changes that occur of both the traditional houses be found in; the foundations, columns, stairs, layout plan, and materials. While differences be found in, form/design, beams, walls, floors, doors / windows, the roof construction and ornaments

Notes :

1. Refer to reference no.1) p.68, the progress of education and communication facilities have accelerated the process of change with very incessant.The changes of traditional values were accompanied ability of weak economy have affected conditions of architecture become very simple

2. Refer to reference, Karsono, Danarti. "Pergeseran Nilai Budaya pada Bangunan Rumah Tradisional Jawa”, 2011 
Journal of Educational Method and Technology Vol. 2 No. 2, Agustus 2019

P-ISSN 2622-8459 E-ISSN 2622-8467

http://ejournal.unima.ac.id/index.php/jemtec

3. Refer to reference no.6) p.66, and refer to reference no.4) p.8 Minahasa in the 19 th century was still covered by dense forests. The types of wood used such as Iron wood, Linggua wood, Cempaka wood (Michelia celebia), Nantu wood (Palagium Obtusifolium Burek) and Maumbi wood (Artocarpus Dayphyla Mig)

4. Refer to reference, Harimu Debby A.J, Sherly Wunas :Perubahan Wujud Fisik

Rumah Tradisional Minahasa di Kota Tomohon dan Tondano Provinsi Sulawesi

Utara (desa Tonsea Lama dan desa Rurukan), Jurnal Teknik Universitas

Brawijaya Malang, Vol. XIII no. 1 April 2006

5, 7, 8, 9, Refer to reference Harimu Debby A.J. : Minahasa Arsitektur-Rumah Tradisional dalam Akselerasi Perubahan (1900-2000) p. 66-86

6. Refer to reference no.6) p.76, Traditional house of Minahasa in the period Mawale - wale only have a large space for a big family. One big house inhabited by 10 to 20 families. Koentjaraningrat, 1992:117 consists of more than one nuclear family, but overall is a social entity that is usually very tight and live life together in one place means in the house or yard

10. Refer to reference no. 10) p.306: Next comes a discussion of " the house as a microcosm"touching on subjects such as the house in history and society, the mythical world view and its " microcosmic representation" in the structure of the house, the image of the house as a tree, and the tree as a cosmic symbol. According to the Toraja belief, the concept of dividing the world becomes the bottom, middle and top are applied on tongkonan. The bottom of is a place for the devil, the middle of is place for human and the top of is a place for gods.Based on these ideas, then the Torajan people considers that the Toraja houses is a micro depiction of the world so called "banua" which means the world

11. Refer to reference Dawson, B., \& Gillow, J: The Traditional Architecture of Indonesia. New York: Thames and Hudson.1994 p.115

12. Refer to reference Parinding, Samban C.:Toraja Indonesia`s Mountain Eden, Times Editions, Singapopre, 1988 p.73

13. Refer to reference, Nurdiah Esti A. : Studi Struktur dan Konstruksi Rumah Tradisional Suku Batak,Minangkabau dan Toraja, Laporan Penelitian, p.30

14, 16, 18, 19, 21. Refer to reference, Sumalyo, Yulianto : Kosmologi dalam Arsitektur Toraja, Jurnal Dimensi Teknik Arsitektur vol.29 no.1. The theory of evolution form of the Toraja traditional house. refer on Jean Koubi in his book Rambu Solo (1982), refer on Tangdilinting L. T. Tongkonan (Rumah Adat Toraja) dengan Struktur, Seni dan Konstruksinya, Yayasan Lepongan Bulan. Tana Toraja 1978.

15. Refer to reference Samingoen Sampoerno : Album of Traditional Architecture, $1983 / 1984$ p.66-67

17. Refer to reference no.3). There is no rule in the government to maintain the Tongkonan, because Tongkonan is private property of the family; the decision depends on the result of costumary meeting of the family. 
Journal of Educational Method and Technology Vol. 2 No. 2, Agustus 2019

P-ISSN 2622-8459 E-ISSN 2622-8467

http://ejournal.unima.ac.id/index.php/jemtec

20. Refer to reference Nurdiah Esti A. : Studi Struktur dan Konstruksi Rumah Tradisional Suku Batak,Minangkabau dan Toraja, Laporan Penelitian, p.42-44

22. Refer to reference Stephany Shandra : Transformasi Tatanan Ruang dan Bentuk Pada Interior Tongkonan di Tana Toraja Sulawesi Selatan, Jurnal Jurusan desain Interior Fakultas Seni dan Desain Universitas Kristen Petra Surabaya, 2009

23. Refer to reference Parinding, Samban C.: Toraja Indonesia`s Mountain Eden, Times Editions, Singapore, 1988 p.79

\section{Source of Figures:}

Fig. 1, 2, 4, 5, 7, 11, 21 ; Harimu Debby A.J, Sherly Wunas :Jurnal Teknik Universitas Brawijaya Malang, Vol. XIII no. 1 April 2006

Fig. 3 ; Sumalyo, Yulianto : Kosmologi dalam Arsitektur Toraja, Jurnal Dimensi Teknik Arsitektur vol.29 no.1

Fig. 6, 8, 10, 20, 24, 28 ; Harimu Debby A.J. : Minahasa Arsitektur-Rumah Tradisional dalam Akselerasi Perubahan 1900-2000 p.75-92

Fig. 9, 17, 29; Collection of the author

Fig. 12 Julistiono Eunike K.: The 2005 World Suistainable Building Conference Tokyo 27-29 Sepetember 2005 (SB05 Tokyo)

Fig. 13, 19,; Parinding, Samban C.: Toraja Indonesia`s Mountain Eden, Times Editions, Singapopre, 1988

Fig. 14, 15, 18, 26 ; Samingoen Sampoerno : Album of Traditional Architecture, $1983 / 1984$, p.71-79

Fig. 16, 27 ; Damanik I. I. : Tongkonan Between Traditional and Technology, Journal Duta Wacana Christian University, Yogyakarta, 2012

Fig. 22, 23 ; Stephany Shandra : Transformasi Tatanan Ruang dan Bentuk Pada Interior Tongkonan di Tana Toraja Sulawesi Selatan,2009

Fig. 25 ; Lihawa, H. Rizal :Tipologi Arsitektur Rumah Tinggal, Studi kasus Masyarakat Jawa Tondano (Jaton) di Desa Reksonegoro Kabupaten Gorontalo, Thesis, Sekola Pasca Sarjana Universitas Gadja Mada, Yogyakarta,2006.

Fig. 30, 31 ; Editions Didier Millet : Architecture ;Indonesian Heritage, Archipelago Press, Singapore, 1988

\section{References:}

1) Budihardjo,E.:. Jati Diri Arsitek Indonesia. Alumni. Bandung, 1997

2) Dawson, B., \& Gillow, J: The Traditional Architecture of Indonesia. New York: Thames and Hudson.1994

3) Damanik Imelda I. : Tongkonan Between Traditional and Technology, Journal Duta Wacana Christian University, Yogyakarta, 2012

4) Editions Didier Millet : Architecture ;Indonesian Heritage, Archipelago Press, Singapore, 1988

5) Graafland, N :. Minahasa Masa Lalu Dan Masa Kini. De Minahasa, Haar Verleden en Haar Tegenwoordige toestans. De Erven F. Bohn. Haarlem, 1898.

6) Harimu Debby A.J. : Minahasa Arsitektur-Rumah Tradisional dalam Akselerasi 
Journal of Educational Method and Technology Vol. 2 No. 2, Agustus 2019

P-ISSN 2622-8459 E-ISSN 2622-8467

http://ejournal.unima.ac.id/index.php/jemtec

Perubahan 1900-2000, Yogyakarta, Lintang Rasi Aksara Books, 2013

7) Harimu Debby A.J, Sherly Wunas :Perubahan Wujud Fisik Rumah Tradisional Minahasa di Kota Tomohon dan Tondano Provinsi Sulawesi Utara (desa Tonsea Lama dan desa Rurukan), Jurnal Teknik Universitas Brawijaya Malang, Vol. XIII no. 1 April 2006

8) Julistiono Eunike K.: The Suistainable Traditional System of Tongkonan in Celebes Indonesia, The 2005 World Suistainable Building Conference Tokyo 27-29 Sepetember 2005 (SB05 Tokyo)

9) Karsono, Danarti.:“ Pergeseran Nilai Budaya pada Bangunan Rumah Tradisional Jawa" Jurnal Fakultas Teknik Sipil dan Arsitektur Universitas Tunas Pembangunan Surakarta, 2011

10) Kis-Jovak, Imre Jova.: Banua Toraja: changing patterns in architecture and symbolism among the Sa'dan Toraja, Sulawesi, Indonesia. Amsterdam: Royal Tropical Institute. 1988

11) Lihawa, H. Rizal :Tipologi Arsitektur Rumah Tinggal, Studi kasus Masyarakat Jawa Tondano (Jaton) di Desa Reksonegoro Kabupaten Gorontalo, Thesis, Sekola Pasca Sarjana Universitas Gadja Mada, Yogyakarta,2006.

12) Nurdiah Esti A. : Studi Struktur dan Konstruksi Rumah Tradisional Suku Batak,Minangkabau dan Toraja, Laporan Penelitian No :09/Pen. Arsitektur/UKP/2011, Surabaya.

13) Parinding, Samban C.: Toraja Indonesia`s Mountain Eden, Times Editions, Singapopre, 1988

14) Samingoen Sampoerno : Album of Traditional Architecture, Ministry of Education and Culture Directorate general of Culture Project of Culture Media, 1983/1984

15) Sumalyo, Yulianto : Kosmologi dalam Arsitektur Toraja, Jurnal Dimensi Teknik Arsitektur vol.29 no.1., Universitas Kristen Petra Surabaya, 2001

16) Stephany Shandra : Transformasi Tatanan Ruang dan Bentuk Pada Interior Tongkonan di Tana Toraja Sulawesi Selatan, Jurnal Jurusan desain Interior Fakultas Seni dan Desain Universitas Kristen Petra Surabaya, 2006 